\title{
Analysis of microbiological and serological markers in laboratory diagnostics of animal listeriosis in a veterinary laboratory
}

\author{
O.G. Petrova ${ }^{1, *}$, A.D. Alekseev ${ }^{1}$, I.M. Milshtein ${ }^{2}$, L.I. Drozdova ${ }^{3}$, and U.I. Kundryukova ${ }^{3}$ \\ ${ }^{1}$ Ural state agrarian university, Department of infectious and non-infectious pathology, 42 Karl \\ Liebknecht street, 620075 Yekaterinburg, Russia \\ ${ }^{2}$ Ural state agrarian university, Department of surgery, obstetrics and Microbiology, 42 Karl \\ Liebknecht street, 620075 Yekaterinburg, Russia \\ ${ }^{3}$ Ural state agrarian university, Department of morphology and expertise, 42 Karl Liebknecht street, \\ 620075 Yekaterinburg, Russia
}

\begin{abstract}
The main goal of veterinary specialists is to prevent and eliminate particularly dangerous animal diseases, especially infections transmitted to humans. Listeriosis refers to natural focal diseases common to humans and animals and due to the fact that this infection can be asymptomatic, while the pathogen is stable in the environment, which is a risk of infection of animals and humans. The main task of veterinary specialists working in laboratories is to conduct research on regulatory documents and timely delivery of results. Laboratory diagnostics of animal listeriosis is the main link in preventing the spread of this disease, and proper selection and transportation of material can solve many problems of Listeria isolation and in some cases even reduce the time of diagnosis. The choice of the material research method also plays an important role.
\end{abstract}

\section{Introduction}

Listeriosis is a bacterial disease that is susceptible to domestic and wild animals, including fur - bearing animals and birds, characterized by damage to the nervous system, septicemia, abortion, and the development of fetal defects. Listeria bacteria can also affect food, and humans are susceptible $[1,2,11]$.

Listeriosis is registered all over the world, while in the Russian Federation the incidence of listeriosis among both animals and humans is lower than in Europe. This infectious disease is a major veterinary and biomedical problem, since there is a high probability of human infection from sick animals, as well as through food. Listeria group bacteria are resistant in the environment at low temperatures, so the occurrence of this disease on the territory of a livestock farm causes significant economic damage not only due to its complex diagnosis and mortality of young animals, but also during disinfection measures $[4,5,6]$.

\footnotetext{
* Corresponding author: super.kafedra2013@yandex.ru
} 


\section{Research materials and methods}

The research was conducted in the Sverdlovsk regional veterinary laboratory, at the departments of infectious and non-infectious pathology, morphology and expertise of the Ural state agrarian university. The data were taken on the basis of veterinary reporting forms of the Sverdlovsk regional veterinary laboratory for the period from 2017 to 2019 .

Materials for laboratory research were:

pathological material from cattle;

aborted fetuses from large and small cattle;

flushes from environmental objects;

food products:

meat, offal and semi-finished products from beef, lamb, pork and poultry;

ready-made meat products of all types of animals;

fish products and fish semi-finished products; dairy products; pork fat; preserves for the period 2017- 2019.

According to the regulatory documentation, the pathological material to be examined for listeriosis is:

whole corpse of a small animal; aborted fetuses and their shells;

blood from the heart; parenchymal organs in whole or in parts (liver, kidneys); spleen; affected areas of the lungs.

To detect antibodies to the bacterium Listeria from blood serum in serological studies (serological markers), the compliment binding reaction (RSC) with the use of Listeria antigen was used;

agglutination reaction (RA) using polyvalent Listeria agglutinating serum;

indirect hemagglutination reaction (rnga) using listeriosis antigen inactivated erythrocyte diagnosticum.

To isolate Listeria bacteria from pathological material using bacteriological research methods, microscopy of initial smears - prints, seeding on nutrient media, identification of isolated cultures by cultural - biochemical and tinctorial properties, and a biological sample was performed on laboratory mice.

From food products, bacteria of the genus Listeria (L. monocytogenes) were isolated using bacteriological methods of seeding on nutrient media;

microscopy of grown colonies;

identification of the pathogen using systems for the identification of bacteria of the genus Listeria - API Listeria.

Isolation of bacteria of the genus Listeria from flushes from environmental objects was carried out using bacteriological methods - using primary and secondary enrichment media. Further identification of cultures is performed using GISS media (to identify cultures by cultural and biochemical properties), and a reaction using listeriosis bacteriophages(bacteriological markers) is also used [9-12].

\section{Results and discussion}

In 2017-2019, the study received 474 samples of pathological material from animals for listeriosis. Of these, three samples were positive, which were detected in 2017 and 2018, respectively. The results of monitoring the isolation of Listeria bacteria are presented in table 1 .

Table 1. Monitoring of isolation of Listeria bacteria from pathological animal material

\begin{tabular}{|l|c|c|c|c|c|c|}
\hline \multirow{2}{*}{$\begin{array}{l}\text { Research } \\
\text { material }\end{array}$} & \multicolumn{2}{|c|}{2017} & \multicolumn{2}{c|}{2018} & \multicolumn{2}{c|}{2019} \\
\cline { 2 - 6 } & Total & Number & Total & Number of & Total & Number of \\
\hline
\end{tabular}




\begin{tabular}{|l|c|c|c|c|c|c|}
\hline & $\begin{array}{c}\text { amount } \\
\text { of } \\
\text { material } \\
\text { studied }\end{array}$ & $\begin{array}{c}\text { of } \\
\text { positive } \\
\text { samples }\end{array}$ & $\begin{array}{c}\text { amount } \\
\text { of } \\
\text { material } \\
\text { studied }\end{array}$ & $\begin{array}{c}\text { positive } \\
\text { samples }\end{array}$ & $\begin{array}{c}\text { amount of } \\
\text { material } \\
\text { studied }\end{array}$ & $\begin{array}{c}\text { positive } \\
\text { samples }\end{array}$ \\
\hline $\begin{array}{l}\text { Pathological } \\
\text { material } \\
\text { from cattle }\end{array}$ & 29 & 0 & 12 & 0 & 34 & 0 \\
\hline $\begin{array}{l}\text { Aborted } \\
\text { fetuses from } \\
\text { cattle }\end{array}$ & 60 & 1 & 132 & 0 & 174 & 0 \\
\hline $\begin{array}{l}\text { Pathological } \\
\text { material } \\
\text { from small } \\
\text { cattle }\end{array}$ & 0 & 0 & 2 & 0 & 0 & 0 \\
\hline $\begin{array}{l}\text { Aborted } \\
\text { fetuses from } \\
\text { small cattle }\end{array}$ & 8 & 0 & 12 & 2 & 11 & 0 \\
\hline Total: & $\mathbf{9 7}$ & $\mathbf{1}$ & $\mathbf{1 5 8}$ & $\mathbf{2}$ & $\mathbf{2 1 9}$ & $\mathbf{0}$ \\
\hline
\end{tabular}

When conducting serological research methods of 4692 blood serum samples from animals, three positive results were obtained in 2018(table 2)

Table 2. The number of positive samples for the pathogen Listeria in the blood serum from animals (serological study)

\begin{tabular}{|c|c|c|c|c|c|c|}
\hline \multirow{2}{*}{$\begin{array}{l}\text { Research } \\
\text { material }\end{array}$} & \multicolumn{2}{|l|}{ Year 2017} & \multicolumn{2}{|l|}{ Year 2018} & \multicolumn{2}{|l|}{ Year 2019} \\
\hline & $\begin{array}{l}\text { Total } \\
\text { amount } \\
\text { of } \\
\text { material } \\
\text { studied }\end{array}$ & $\begin{array}{l}\text { Number } \\
\text { of } \\
\text { positive } \\
\text { samples }\end{array}$ & $\begin{array}{l}\text { Total } \\
\text { amount of } \\
\text { material } \\
\text { studied }\end{array}$ & $\begin{array}{l}\text { Number } \\
\text { of positive } \\
\text { samples }\end{array}$ & $\begin{array}{l}\text { Total } \\
\text { amount of } \\
\text { material } \\
\text { studied }\end{array}$ & $\begin{array}{l}\text { Number } \\
\text { of } \\
\text { positive } \\
\text { samples }\end{array}$ \\
\hline $\begin{array}{l}\text { Blood } \\
\text { serum of } \\
\text { cattle }\end{array}$ & 1049 & 0 & 1236 & 3 & 1634 & 0 \\
\hline $\begin{array}{l}\text { Blood } \\
\text { serum from } \\
\text { small cattle }\end{array}$ & 149 & 0 & 414 & 0 & 194 & 0 \\
\hline $\begin{array}{l}\text { Blood } \\
\text { serum from } \\
\text { pigs }\end{array}$ & 13 & 0 & 2 & 0 & 0 & 0 \\
\hline $\begin{array}{l}\text { Blood } \\
\text { serum from } \\
\text { horses }\end{array}$ & 1 & 0 & 0 & 0 & 0 & 0 \\
\hline Total: & 1212 & $\mathbf{0}$ & 1652 & 3 & 1828 & 0 \\
\hline
\end{tabular}

For veterinary - sanitary examination of food products for the presence of bacteria of the genus Listeria (L. monocytogenes) in a laboratory guide meat, offal and semi-finished products from beef, lamb, pork,poultry and other animal species; prepared meat products of all species; fish products, fish and fish by-products; dairy products; animal fat, pork fat; preserved foods; other foods (broth fish, products, catering, pastries)[7,8,13,18].

In 2017-2019, the study received 6511 samples of food samples. They include meat, offal and semi-finished products. 71 samples were positive . Listeria monocytogenes was detected in samples of meat, offal and semi-finished products from beef, pork, poultry, finished meat products,fish and fish semi-finished products, and other food products(table $3)$. 
Table 3. Monitoring the isolation of Listeria monocytogenes bacteria from food

\begin{tabular}{|c|c|c|c|c|c|c|}
\hline \multirow{2}{*}{$\begin{array}{l}\text { Research } \\
\text { material }\end{array}$} & \multicolumn{2}{|c|}{2017} & \multicolumn{2}{|c|}{2018} & \multicolumn{2}{|c|}{2019} \\
\hline & $\begin{array}{l}\text { Total } \\
\text { amount of } \\
\text { material } \\
\text { studied }\end{array}$ & $\begin{array}{l}\text { Number } \\
\text { of } \\
\text { positive } \\
\text { samples }\end{array}$ & $\begin{array}{l}\text { Total } \\
\text { amount of } \\
\text { material } \\
\text { studied }\end{array}$ & $\begin{array}{l}\text { Number } \\
\text { of } \\
\text { positive } \\
\text { samples }\end{array}$ & $\begin{array}{l}\text { Total } \\
\text { amount of } \\
\text { material } \\
\text { studied }\end{array}$ & $\begin{array}{l}\text { Number } \\
\text { of } \\
\text { positive } \\
\text { samples }\end{array}$ \\
\hline $\begin{array}{l}\text { Beef meat, } \\
\text { offal and semi- } \\
\text { finished } \\
\text { products }\end{array}$ & 172 & 7 & 247 & 2 & 216 & 3 \\
\hline $\begin{array}{l}\text { Lamb meat, } \\
\text { offal and semi- } \\
\text { finished } \\
\text { products }\end{array}$ & 1 & 0 & 10 & 0 & 4 & 0 \\
\hline $\begin{array}{l}\text { Meat, offal and } \\
\text { semi-finished } \\
\text { products from } \\
\text { pork }\end{array}$ & 416 & 2 & 409 & 5 & 515 & 0 \\
\hline $\begin{array}{l}\text { Poultry meat, } \\
\text { offal and semi- } \\
\text { finished } \\
\text { products }\end{array}$ & 142 & 4 & 245 & 16 & 179 & 13 \\
\hline $\begin{array}{l}\text { Meat, offal and } \\
\text { semi-finished } \\
\text { products from } \\
\text { other animal } \\
\text { species }\end{array}$ & 2 & 0 & 9 & 0 & 2 & 0 \\
\hline $\begin{array}{l}\text { Ready-made } \\
\text { meat products } \\
\text { of all types of } \\
\text { animals }\end{array}$ & 185 & 5 & 474 & 0 & 465 & 2 \\
\hline $\begin{array}{l}\text { Fish, fish semi- } \\
\text { finished } \\
\text { products }\end{array}$ & 49 & 3 & 139 & 0 & 239 & 0 \\
\hline Fish products & 17 & 1 & 71 & 5 & 100 & 2 \\
\hline Caviar, milt & 0 & 0 & 0 & 0 & 11 & 0 \\
\hline Milk products & 415 & 0 & 515 & 0 & 460 & 0 \\
\hline $\begin{array}{l}\text { Animal fat, } \\
\text { pork fat }\end{array}$ & 6 & 0 & 1 & 0 & 9 & 0 \\
\hline Preserves & 9 & 0 & 4 & 0 & 4 & 0 \\
\hline $\begin{array}{l}\text { Other products } \\
\text { (fish broth, } \\
\text { food service } \\
\text { products, } \\
\text { confectionery) }\end{array}$ & 78 & 1 & 625 & 0 & 66 & 0 \\
\hline Total: & 1492 & 23 & 2749 & 28 & 2270 & 20 \\
\hline
\end{tabular}

In connection with positively detected samples of pathological material in 2017 and 2018, feed for isolating Listeria group bacteria was sent to the laboratory from farms where the causative agent of listeriosis was isolated. Bacteriological and biological studies of feed were carried out, as well as microscopy. No positive results were found(table 4).

Table 4. Monitoring of the isolation of Listeria bacteria from feed

\begin{tabular}{|l|l|l|l|l|l|}
\hline \multirow{2}{*}{$\begin{array}{l}\text { Research } \\
\text { material }\end{array}$} & \multicolumn{3}{|c|}{2017} & \multicolumn{3}{c|}{2018} \\
\cline { 2 - 6 } & Total amount & Number of & Total amount & Number of & positive \\
\hline
\end{tabular}




\begin{tabular}{|c|c|c|c|c|}
\hline & $\begin{array}{l}\text { of material } \\
\text { studied }\end{array}$ & $\begin{array}{l}\text { positive } \\
\text { samples }\end{array}$ & $\begin{array}{l}\text { of material } \\
\text { studied }\end{array}$ & samples \\
\hline $\begin{array}{l}\text { Feed from } \\
\text { livestock farms }\end{array}$ & 4 & 0 & 1 & 0 \\
\hline Total: & 4 & 0 & 1 & 0 \\
\hline
\end{tabular}

Environmental objects to be investigated for the presence of Listeria bacteria were flushes selected from various objects: flushes from equipment, walls, packaging of finished products, workwear, from the hands of workers in the meat industry; flushes from equipment, walls, workwear, from the hands of workers in the fishing industry; flushes from equipment, walls, large containers and packaging, workwear, from the hands of workers in the dairy industry; flushes from equipment, walls, workwear, from the hands of workers in slaughterhouses; flushes from equipment, walls, small and large inventory for quality control of disinfection before and after disinfection measures; flushes from equipment, work clothes and hands of workers, walls at poultry processing enterprises; flushes from large and small inventory of fur-bearing animals; other flushes[3,15,16].

In $2017-2019$, the study received 15,675 samples of flushes for bacteria of the genus Listeria. There were no positive results (table 5).

Table 5. Monitoring the isolation of Listeria bacteria from flushes from environmental objects.

\begin{tabular}{|l|c|c|c|c|c|c|}
\hline Research \\
material
\end{tabular}

Veterinary laboratories of the Russian Federation use methods of bacteriological and serological markers - serological identification of Listeria using diagnostics for RSC Listeria antigen; method of bacteriological identification of Listeria from flushes from environmental objects using primary and secondary accumulation media, as well as other 
nutrient media and GISS media to establish the biochemical and tinctorial properties of the pathogen; to isolate Listeria bacteria from food products, in addition to nutrient media, API Listeria dies are used for faster identification of the culture.

In laboratories with a low research ceiling, it is not advisable to use expensive methods. For example, the method using Listeria bacteriophages. A set of listeriosis bacteriophages for identifying Listeria and setting the phage titer increase reaction should be used in laboratories with a high flow of research on listeriosis. The use of primary and secondary enrichment media is advisable, since these media are dry combined media, have a high shelf life, low consumption for research, and pay off even at low prices for the study itself $[14,17,19]$.

Taking into account the data of the regulatory documentation for 2017-2019, we can conclude that the amount of material sent to the laboratory for testing for listeriosis has increased, despite the fact that not all agricultural enterprises and food production enterprises conduct diagnostic tests for this disease. Listeriosis is not included in the list of mandatory studies, as well as bacteriological examination of flushes, pathological material and food products is expensive.

Despite this, the case from the practice of pok a shows that when allocating a positive result, agricultural enterprises strictly observe veterinary and sanitary measures.

According to the regulatory documentation, it is possible to track the implementation of anti-epizootic measures on farms where positive cases of listeriosis have been identified. In April 2018, L. monocytogenes was isolated from the stomach of an aborted fetus from an Alpine goat. After receiving a positive result, restrictions were imposed on the operation of the farm in order to prevent the occurrence and spread of the disease. During the week, samples of alfalfa haylage from different areas where animals were kept were sent to the laboratory for research. The bacteriological study did not isolate the causative agent of listeriosis from the sent material. Flushes from environmental objects before and after disinfection measures were also sent to the laboratory. The flushes also did not contain Listeria bacteria, after which the farm was declared safe for this disease.

The Sverdlovsk region is safe for listeriosis, but there are cases of isolation of bacteria not only from pathological material, but also from food products. These are mostly raw or ready - made meat products from different types of animals, and if veterinary and sanitary rules are not followed, such products can end up on the shelves of stores, thereby causing an outbreak of listeriosis among people.

This disease is dangerous because it can occur without clinical signs, which can make it difficult to diagnose, and Listeria bacteria are resistant to environmental objects and can persist for a long time even at low temperatures.

To prevent outbreaks of epizootics, farms should carefully monitor the sanitary condition of the farm, take flushes from environmental objects according to the schedule, and if listeriosis is suspected in animals, immediately send pathological material and aborted fetuses to the laboratory for research.

To prevent Listeria bacteria from entering food products or getting Listeria bacteria on the shelves of food stores, it is necessary to carefully monitor the sanitary condition of production, take flushes according to the schedule, monitor the cleanliness of workers ' hands, cleaning equipment, check food products for listeriosis (especially raw products such as lard, or finished products - confectionery).

\section{Conclusions}

Analysis of data on the incidence of listeriosis of farm animals for the period 2017 2019 in the Sverdlovsk region showed an increase in the number of positive results every year. The Sverdlovsk region remains safe for this disease, but the data show that the 
problem of diagnosis, prevention and treatment of listeriosis should be treated more carefully.

The results of data on the number of studies sent to the laboratory for listeriosis indicate that the number of studies for 2017 - 2019 increased. In 2018, compared to 2017, the study of pathological material for listeriosis increased by $62.8 \%$, and if we compare 2019 and 2018 , the number of studies increased by $38.6 \%$ in 2019 . The number of serological studies of animal serum in 2018 was $36.3 \%$ higher than in 2017, and in 2019 it was $10.6 \%$ higher than in 2018. The study of food products with bacteriological markers in 2018 increased by $84.2 \%$ compared to 2017 , but in 2019 , compared to 2018 , it decreased by $17.4 \%$. The number of flushes studied varies slightly over the course of all three years.

The diagnostic significance and effectiveness of using both bacteriological and serological markers is that these studies among animals can identify not only patients, but also Listeria carriers, which greatly facilitates the work of veterinary workers. Even in the absence of clinical signs, it is possible to detect the presence of Listeria bacteria in the body of animals for immediate veterinary measures.

\section{Acknowledgements}

We would like to thank Natalia Syutkina, Director of THE Sverdlovsk regional veterinary laboratory, and A.S. Varfolomeeva, veterinarian, for their help in writing the article

\section{References}

1. S.T. Antipov, Innovative development of food technology technology (M.:"LAN", 2016)

2. I.A. Bakulov, D.A. Vasiliev, D.V. Kolbasov, E.N. Kovaleva, I.Yu. Egorova, Yu.O. Selyaninov, Listeria and listeriosis, (Ulyanovsk: Colorprint, 2016. - 336 p.

3. D.S. Bataeva, Yu.K. Yushina, E.V. Zaiko, Theory and practice of meat processing, 1(2), 34-41(2016)

4. D.S. Bataeva, Yu.K. Yushina, O.V. Sokolova, E.V. Zaiko, All about meat, 3, 3-5 (2017)

5. E.V.Belousova, Meat industry, 11, 18-21 (2016)

6. L.G. Boronina, E.V. Samatova, O.S. Chernyshova, Modern problems of control over the spread of Listeria and infections caused by Listeria monocytogenes, 116 - 119 (2016)

7. M.P. Butko, Problems of veterinary sanitation, hygiene and ecology, 1(13), 39-48 (2015)

8. M.A. Vasilieva, V.G. Urban, Issues of legal regulation in veterinary medicine, 1, 229232 (2019)

9. GOST 7269-79 Meat. Sampling methods and organoleptic methods for determining freshness.

10. GOST R 51447-99 (ISO 3100-1-91) Meat and meat products. Sampling methods - for poultry meat.

11. GOST R 51447-99 Meat and meat products. Sampling method.

12. GOST R 51478-99 (ISO 2917-74) Meat and meat products. Control method for determining the concentration of hydrogen ions $(\mathrm{pH})$.

13. V.A. Dolgov, Problems of veterinary sanitation, hygiene and ecology, 1(13), 16-23 (2015)

14. I.V. Kozyrev, I.M. Milshtein, Food industry, 4, 56-58 (2016) 
15. A.K. Musaeva, N.N. Egorova, A.T. Daugaliou, M.K. Kozhabayev, Scientific review. Biological Sciences, 1, 83-89 (2016)

16. O.G. Petrova, A.S. Varfolomeeva, Medicus, 3(33), 8-13 (2020)

17. Draft Order of the Ministry of agriculture of the Russian Federation "On approval of Veterinary rules for the implementation of preventive, diagnostic, therapeutic, restrictive and other measures, the establishment and cancellation of quarantine and other restrictions on the territory of the Russian Federation aimed at preventing the spread and elimination of foci of listeriosis". (prepared by the Ministry of agriculture of Russia 23.03.2016)

18. M.A. Sinelnikova, B.S. Buzoleva, N.Yu. Bespechuk, G.G. Koltun, Shgigien and sanitation, 96(6) (2017)

19. N.M. Haptanova, N.M. Andreevskaya, S.V. Lukyanova, Zh.A. Konovalova, N.G. Gefen, A.S. Ostyak, E.G. Tokmakova, ActaBiomedica Scientifica, 4(1), 43-49 (2019) 